\title{
Trends and ISDS Backlash Related to Non-Disputing Treaty Party Submissions
}

\author{
Kendra Magraw
}

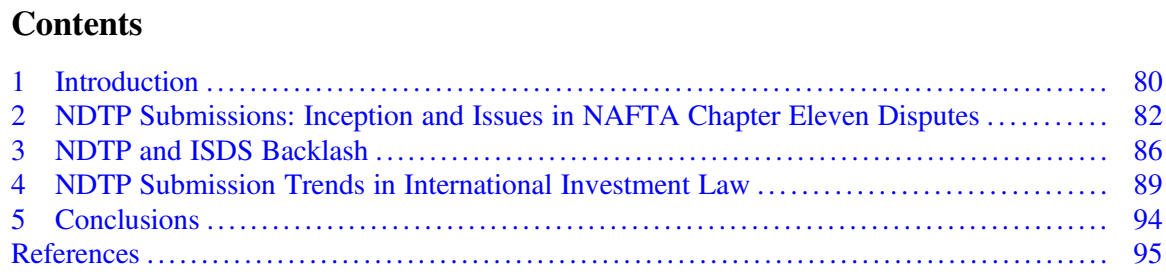

\begin{abstract}
Some international investment agreements (IIAs) allow states that are parties to a treaty, but are not party to a specific dispute under that treaty, to intervene on a limited basis in order to make submissions on matters of treaty interpretation. Such mechanisms have proved to be highly valued by treaty parties, as evident by the many recently-concluded IIAs containing increasingly sophisticated non-disputing treaty party (NDTP) provisions. This chapter: (1) provides the background on NDTPs mechanisms, with a focus on the North American Free Trade Agreement (NAFTA) (the first-known IIA to contain such a provision); (2) examines the possible connection between tribunals failing to give due regard to treaty parties' interpretive positions (again focusing on NAFTA) and the current backlash against investor-state dispute settlement (ISDS); and (3) analyses trends in recentlyconcluded IIAs. It is argued that the apparent lack of deference given by tribunals to NDTP submissions may be contributing to the current backlash against ISDS, based on two discernible trends: (1) an increase in the number of IIAs containing NDTPs provisions; and (2) provisions that now state that not only are treaty interpretations made by treaty parties binding on tribunals (such provisions also have their genesis in NAFTA), but that, in addition, tribunals' decisions must be
\end{abstract}

\footnotetext{
K. Magraw ( $\square)$

Graduate Institute of International and Development Studies (IHEID), Geneva, Switzerland 
consistent with such agreed interpretations (the latter an innovation of a NAFTA party in 2003). Such trends are also visible at the institutional and multilateral levels, such as the revision of the Arbitration Rules of the International Centre for Settlement of Investment Disputes (ICSID) and the Mauritius Convention on Transparency in ISDS of the United Nations Commission on International Trade Law (UNCITRAL), and show no sign of slowing down.

\section{Introduction}

One unusual aspect of international investment dispute settlement that has developed since its early days and has gained increasing momentum in recent years is that certain international investment agreements (IIAs) allow states that are parties to a treaty, but are not parties to a specific dispute under that treaty, to intervene in the dispute on a limited basis in order to make submissions on matters of treaty interpretation. ${ }^{1}$ For example, Article 1128 of the North American Free Trade Agreement (NAFTA) permits its non-disputing treaty parties (NDTPs) to file submissions in ongoing cases regarding their interpretations of NAFTA. ${ }^{2}$ This feature was probably employed due to the nature of investor-state dispute settlement (ISDS), in which treaty partners do not appear as opposing parties in a given dispute; instead, only one party to a treaty is typically a respondent in a dispute.

The submissions made by NDTPs are distinct from amicus curiae submissions, in that NDTP submissions are only available to treaty parties that are not party to the dispute-at-hand, and almost always only on matters of treaty interpretation. ${ }^{3}$ NDTPs

\footnotetext{
${ }^{1}$ Other international adjudicative regimes provide for third party participation in disputes, but that can often be circumnavigated (for example, in the World Trade Organization (WTO), whether third parties may participate in a dispute depends on whether the dispute is brought pursuant to Article XXII of the General Agreement on Tariffs and Trade (GATT), Article XXII:1 of the General Agreement on Trade in Services (GATS), Article 4.11 of the Dispute Settlement Understanding (DSU) or other corresponding provisions in the covered agreements-all of which allow third party participation (so long as they are WTO Members) - versus Article XXII:1 of the GATT, under which the participation of a third party is subject to approval from the respondent) or are subject to obtaining leave to intervene (see, e.g. Palchetti 2002, p. 139).

${ }^{2}$ Article 1128 of the North American Free Trade Agreement (NAFTA) (adopted 17 December 1992), (1993) 32 International Legal Materials 612.

${ }^{3}$ Only the 2014 UNCITRAL Rules on Transparency in Treaty-based Investor-State Arbitration (Rules on Transparency) allow for the possibility of NDTP submissions on matters other than treaty interpretation (which is also permitted thereunder, see Article 5(1)), providing in this regard in Article 5(2) that:
}

The arbitral tribunal, after consultation with the disputing parties, may allow submissions on further matters within the scope of the dispute from a non-disputing Party to the treaty. In determining whether to allow such submissions, the arbitral tribunal shall take into consideration, among other factors it determines to be relevant, the factors referred to in article 4 , paragraph 3 , and for greater certainty, the need to avoid submissions which would support the claim of the investor in a manner tantamount to diplomatic protection. 
are also distinct from intervening parties, whose scope of participation in the dispute is much broader. Many modern IIAs recognise these distinctions by, e.g. having separate provisions governing the participation of NDTPs and non-disputing parties (NDPs) - e.g. civil society—more generally. ${ }^{4}$ As will also be discussed below, such distinction can further be seen in the situation that has arisen with respect to the participation in investor-state disputes of the European Union (EU), a regional economic union that only obtained treaty-making power in relation to foreign direct investment with the Lisbon Treaty's entry into force in $2009,,^{5}$ and which is not a party to many of its member states' treaties, meaning that it is an NDP as opposed to an NDTP in disputes arising under such treaties. The EU has had difficulty successfully petitioning to participate in ongoing disputes involving its member states, which may be contributing not only to the EU's current attempt post-Achmea ${ }^{6}$ to enforce the termination of its member states' intra-EU treaties and create a standing international investment court with an appeals mechanism, but also its current treaty practice in concluding new IIAs, which contain NDTP mechanisms. ${ }^{7}$

The increasing value that states seem to be placing on the availability of NDTP submission mechanisms is evident in part by the many recently-concluded treaties that contain similar provisions to NAFTA Article 1128-for example, slightly over one third of the known IIAs concluded in 2018 contained such mechanisms. ${ }^{8}$ This trend does not come as a complete surprise: since the explosion of investment disputes in the 1990s/2000s, states have frequently resorted to their ability to submit NDTP submissions, above all in the NAFTA context, in which NAFTA Article 1128 submissions have been made by the NDTPs in at least 33 known-NAFTA cases. ${ }^{9}$

However, as will also be discussed further below, while arbitral tribunals frequently cite NDTP submissions, they also have appeared reluctant to afford much interpretive weight to the agreements reached by the parties in their submissions, although a few tribunals have. ${ }^{10}$ In the NAFTA context, which will be the main

\footnotetext{
${ }^{4}$ Compare e.g. Article 14.D.7(2) of the United States-Mexico-Canada Agreement (USMCA), which permits NDTP submissions, and Article 14.D.7(3) of the USMCA, which permits amicus submissions.

${ }^{5}$ Article $188 \mathrm{~L}$ of the Treaty of Lisbon Amending the Treaty on European Union and the Treaty Establishing the European Community, 2007.

${ }^{6}$ CJEU, Slovakia v. Achmea, Case C-284/16, EU:C:2018:158. For an explanation of Achmea, see Ankersmit L. (2018) Achmea: The Beginning of the End for ISDS in and with Europe?, IISD, https://www.iisd.org/itn/2018/04/24/achmea-the-beginning-of-the-end-for-isds-in-and-witheurope-laurens-ankersmit/\#_edn1.

${ }^{7}$ See Article 3.51 of the EU-Vietnam investment protection agreement (IPA) (2019), Article 3.17 of the EU-Singapore IPA (2018) and Article 8.38 of the Canada-European Union Comprehensive Economic and Trade Agreement (CETA) (2016).

${ }^{8}$ See Investment Policy Hub, IIA Navigator, https://investmentpolicy.unctad.org/internationalinvestment-agreements; UNCTAD, Taking Stock of IIA Reform: Recent Developments, IIA Issues Note No. 3, June 2019, https://unctad.org/en/PublicationsLibrary/diaepcbinf2019d5_en.pdf.

${ }^{9}$ Furthermore, there are often multiple NDTP submissions made in a given case.

${ }^{10}$ See Magraw (2015), p. 142.
} 
focus of this chapter, such reluctance on the part of tribunals eventually resulted in the NAFTA parties taking the next step and issuing binding interpretive statements (which are permitted under NAFTA), ${ }^{11}$ in order to attempt to force the recognition of their agreements. Such reluctance on the part of tribunals, it is argued herein, may be contributing to the current backlash against ISDS by states and other stakeholders in the investment law regime.

This chapter addresses certain aspects of NDTP participation-especially submissions - in international investment law. Section 2 provides the background of NDTP mechanisms, as well as issues that have arisen with respect to them, especially in the NAFTA context. Section 3 examines the possible connection between failing to give due regard to the interpretive positions offered by treaty parties and the current backlash against ISDS. Finally, Sect. 4 analyses trends in a sample of recently-concluded IIAs and other related initiatives with respect to NDTP submissions. ${ }^{12}$

From a methodological perspective, it is important to note that the IIA data analysed in this chapter to identify, e.g., trends in IIA treaty-making, does not purport to be a comprehensive examination of every known IIA. Rather, analysis was carried out in two steps: the first being the identification of a base group of IIAs (via the UNCTAD IIA Mapping Project and other sources) ${ }^{13}$ that are known to contain the provisions whose prevalence in IIAs is analysed herein; and second, once the base group of IIAs was identified by reference to the sources indicated, this base group was expanded upon by comprehensively examining the treaties of specific states whose treaties the author hypothesised might contain the analysed provisions (obviously for purposes of this chapter, the NAFTA parties' IIAs were all examined, for example). It is therefore possible that the underlying data upon which the discussion in this chapter is based on the available resources and/or skewed in favour of the informed fishing expedition undertaken by the author: this notwithstanding, it is argued that the available data supports the trends identified herein.

\section{NDTP Submissions: Inception and Issues in NAFTA Chapter Eleven Disputes}

When NAFTA came into force in 1994, it could probably be considered to have been the most comprehensive and sophisticated free trade agreement (FTA) that had ever been concluded: not only were FTAs relatively uncommon at that time, since international trade was governed almost exclusively by the multilateral General

\footnotetext{
${ }^{11}$ Articles 2001 (2) and 1131(2) of NAFTA.

${ }^{12}$ UNCTAD Mapping Project, https://investmentpolicy.unctad.org/international-investment-agree ments/iia-mapping.

${ }^{13}$ For example, UNCTAD, World Investment Report 2019, UN, p. 108, Table III.3, https://unctad. org/en/PublicationsLibrary/wir2019_en.pdf [hereinafter "UNCTAD 2019 WIR"]; Gordon and Pohl (2015) and Polanco (2019).
} 
Agreement on Tariffs and Trade (GATT), but in addition, while subsequently it became common for countries to include investment chapters or provisions in their trade agreements, NAFTA was one of the first to do so. Further, NAFTA's investment chapter, Chapter Eleven, was much more detailed than the typical bilateral investment treaty (BIT) that was being concluded in hordes in the 1990s (the typical BIT at that time had between eleven and thirteen provisions, while NAFTA had thirty-nine).

One of NAFTA's innovative features is that it is the first-known IIA to introduce an NDTP provision, i.e. Article 1128, which provides that "[o]n written notice to the disputing parties, a [NAFTA] Party may make submissions to a Tribunal on a question of interpretation of this agreement." In practice, since the first disputes brought under NAFTA, the NAFTA parties have frequently exercised their right to file submissions on matters of treaty interpretation in ongoing disputes (to date, non-disputing NAFTA parties have filed NDTP submissions in at least 33 NAFTA cases), ${ }^{14}$ which led to novel and controversial situations in international investment law.

For example, in several early NAFTA disputes, it was debated whether NAFTA's fair and equitable treatment (FET) provision (NAFTA Article 1105) was subsumed by the customary international law (CIL) minimum standard of treatment (MST) or whether it was a stand-alone obligation. The three NAFTA parties (Canada, Mexico and the United States) argued in multiple cases (e.g. in Mondev v. United States, ${ }^{15}$ Loewen v. United States, ${ }^{16}$ Methanex v. United States ${ }^{17}$ and Pope \& Talbot v. Canad $^{18}$ ) that their pleadings (herein referred to as "state party pleadings" or

\footnotetext{
${ }^{14}$ See e.g. Halow.com.

${ }^{15}$ The United States argued that the SPPs of the parties-that is "formal, public submissions to various Chapter Eleven tribunals"- amounted to subsequent practice establishing an agreement under Article 31(3)(b) of the Vienna Convention on the Law of Treaties, 1969 (VCLT) that was binding on the tribunal. Mondev International Ltd v. United States, ICSID Case No. ARB(AF)/99/ 2, Counter-Memorial on Competence and Liability of Respondent United States, 1 July 2001, pp. 33-34.

${ }^{16}$ The United States argued that its SPPs in Loewen and Mexico and Canada's SPPs from domestic proceedings amounted to subsequent practice establishing an agreement under VCLT Article 31(3) (b), and that this should be given considerable weight. Loewen, Group, Inc and Raymond L Loewen v. United States of America, ICSID Case No. ARB(AF)/98/3, Counter-Memorial, 30 March 2001, pp. 175-176.

${ }^{17}$ All three parties argued that they were in agreement: the United States in its pleadings as the respondent in Methanex, and Canada and Mexico via NAFTA Article 1128 mechanism in Methanex. See Methanex v. United States, UNCITRAL, Post-Hearing Submission of Respondent United States of America, 20 July 2001, pp. 2-4. See also Methanex v. United States, UNCITRAL, Response of Respondent United States of America to Methanex's Post-Hearing Submission, 27 July 2001, pp. 2-6.

${ }^{18}$ Pope \& Talbot v. Canada, UNCITRAL, Canada's Submission respecting Post-Hearing Article 1128 Submission filed by Mexico and the US, 1 June 2000.
} 
"SPPs"), including their NDTP submissions, established an agreement on the interpretation of NAFTA under Article 31(3)(a) of the Vienna Convention on the Law of Treaties (VCLT). ${ }^{19}$

Pope \& Talbot played a starring role in this debate; therein, the respondent state, Canada, argued that all three NAFTA parties agreed in their SPPs-Canada in its memorials, and Mexico and the United States in their NAFTA Article 1128 NDTP submissions - that NAFTA Article 1105 reflected the CIL FET standard. ${ }^{20}$ However, in an interim award, while the tribunal noted the parties' agreement on the interpretation of NAFTA Article 1105 in their pleadings, it ultimately dismissed such agreement because of, inter alia, concerns that the interpretation did not reflect the parties' true intentions at the time NAFTA was drafted. ${ }^{21}$ Approximately three months later, while not only Pope \& Talbot but also several cases on the matter remained pending, the NAFTA parties issued a binding joint interpretive statement, the 31 July 2001 Free Trade Commission (FTC) "Notes of Interpretation of Certain Chapter 11 Provisions" (FTC Notes), linking FET to CIL. As a result, the Loewen, Mondev and Methanex tribunals found that they did not have to determine the status of the parties' interpretive agreements in their submissions; rather they applied the FTC Notes. $^{22}$

However, the saga did not end there: the Pope \& Talbot tribunal, which still had to issue its final Award, refused to apply the freshly-issued FTC Notes, determining instead that even though interpretations issued by the FTC are binding, tribunals have the power to determine whether an alleged interpretation is actually an interpretation or rather a disguised amendment. ${ }^{23}$ Perhaps on no other occasion in the history of NAFTA Chapter Eleven has the outcry from the legal community been

\footnotetext{
${ }^{19}$ Vienna Convention on the Law of Treaties (adopted 23 May 1969), 155 United Nations Treaty Series 331. For an examination of SPPs in relation to subsequent agreement and subsequent practice in ISDS, see Magraw (2015), p. 142.

${ }^{20}$ Canada also argued the same with regard to NAFTA's expropriation provision, Article 1110. Pope \& Talbot v. Canada, UNCITRAL, Canada's Submission respecting Post-Hearing Article 1128 Submissions filed by Mexico and the US, 1 June 2000.

${ }^{21}$ Pope \& Talbot v. Canada, UNCITRAL, Award on the Merits of Phase 2, 10 April 2001, para. 79 , pp. $112-114$

${ }^{22}$ For example, the Methanex tribunal determined that the FTC Notes were a subsequent agreement under Article 31(3)(a) of the VCLT and stated that it was therefore unnecessary for it to decide whether the parties' SPPs were an agreement. Methanex v. United States of America, UNCITRAL, Final Award, 3 August 2005, (2005) 44 International Legal Materials 1345, part II, ch B, para. 21. However, the Pope \& Talbot tribunal defiantly refused to apply the FTC Notes in its subsequent award. See Pope \& Talbot v. Canada, NAFTA, Decision in Respect to Damages, 31 May 2002, 41 International Legal Materials 347, paras 11-16.

${ }^{23}$ Pope \& Talbot v. Canada, UNCITRAL, Decision in Respect to Damages, 31 May 2002, para. 47. The tribunal's action also caused a backlash amongst the NAFTA parties and is the likely genesis of subsequent treaty practice that can be observed in certain of the treaties concluded thereafter by the NAFTA parties, which has also been taken up by other states. See Sect. 2 of this chapter.
} 
more vocal, particularly since the FTC Notes affected ongoing arbitrations, raising issues of, inter alia, circumvention of due process and retroactivity. ${ }^{24}$

Furthermore, other arbitral tribunals found ways to sidestep the FTC Notes, even if they recognised that they were binding per the terms of NAFTA. For example, in the Merrill \& Ring Forestry v. Canada case, which was initiated in 2006, the issue again arose concerning the meaning of the FET standard in relation to CIL. While the Merrill \& Ring tribunal accepted that the 2001 FTC Notes were binding according to NAFTA's provisions, the tribunal noted that the interpretations in the FTC Notes may not reflect the current state of CIL, the "evolutionary nature" of which the tribunal was "mindful of" and "which provides scope for the interpretation of [NAFTA's FET article], even in the light of the FTC Commission's 2001 interpretation." 25

The respondent, Canada, argued that if an evolutionary interpretation of FET was appropriate at all, such evolution must have occurred subsequent to the issuance of the FTC Notes, and that no such subsequent evolution of the standard had taken place. The tribunal disagreed, effectively sidestepping the contents of the FTC Notes, ${ }^{26}$ and proceeded to re-analyse the CIL standard that the FTC Notes tied to FET $^{27}$ (which the tribunal even noted that Canada had adhered to as the relevant standard in its SPPs in other NAFTA disputes ${ }^{28}$ ), before instead concluding that there was a specialised FET standard in business, trade and investment. ${ }^{29}$

The FTC Notes and their raison d'être were not only influential in NAFTA disputes, but have also been taken into consideration in other ISDS cases. For example, in a separate opinion in one ISDS case, arbitrator Pedro Nikken relied on the FTC Notes as an indication as to why the majority's "disguised recourse to

\footnotetext{
${ }^{24}$ See Pope \& Talbot v. Canada, UNCITRAL, Decision in Respect to Damages, 31 May 2002, paras 11-16; Alvarez and Park (2006), p. 347; Brower II (2001), pp. 43, 56 and fn 71; Brower II (2006), p. 347; Weiler (2002), pp. 45, 346-348; Matiation (2014), p. 451; Methanex Corporation v. United States of America, UNCITRAL, Decision on Jurisdiction and Merits, 3 August 2005, Part IV, Chapter C, para. 22.

${ }^{25}$ Merrill \& Ring Forestry LP v. Canada, ICSID Case No. UNCT/07/1, Award, 31 March 2010, paras 190 and 192.

${ }^{26}$ The tribunal stated that the FTC Notes "does not refer to the specific content of [CIL] at a given moment and it is not an interpretative note of such content. Accordingly, the matter needs to be examined in the light of the evolution of customary law over time"; Merrill \& Ring Forestry LP $v$. Canada, ICSID Case No. UNCT/07/1, Award, 31 March 2010, para. 194.

${ }^{27}$ The Neer standard established by the Mexico-United States General Claims Commission. See LFH Neer \& Pauline Neer (USA) v. United Mexican States, Decision, 15 October 1926 (1951) 4 Reports of International Arbitral Awards 60.

${ }^{28}$ Merrill \& Ring Forestry LP v. Canada, ICSID Case No. UNCT/07/1, Award, 31 March 2010, para. 195.

${ }^{29}$ Merrill \& Ring Forestry LP v. Canada, ICSID Case No. UNCT/07/1, Award, 31 March 2010, para. 200.
} 
evolutionary interpretation" was inappropriate, ${ }^{30}$ since the NAFTA parties issued the FTC Notes precisely "as a reaction to" ISDS tribunals' interpretations that the NAFTA parties considered to be incorrect and "which went beyond what those States had considered the extent of their obligations under the [NAFTA]."31

As will be discussed below, the NAFTA parties' experience with respect to NDTP submissions and whether the parties' interpretive agreements are binding on tribunals have had a significant effect both on their treaty practice, as well as the practice of third states. It is also clear that states were not satisfied with the lack of deference that tribunals seemed to give the interpretations put forth in NDTP submissions, and in some instances, have adopted policies designed to strengthen their control in the interpretive process or to change the system altogether.

\section{NDTP and ISDS Backlash}

Failures such as those described above to give due regard to the interpretive value of NDTP submissions may, in conjunction with other factors, be contributing to the current "backlash" against ISDS. In general, such backlash has been ongoing for the last several years and has manifested itself in a variety of ways, including: (1) states disengaging entirely from the ISDS regime, i.e. by terminating their IIAs or by leaving important multilateral conventions, such as the Convention on the Settlement of Investment Disputes between States and Nationals of Other States (ICSID Convention); (2) states renegotiating the terms of their existing IIAs, for instance to provide for restricted access to ISDS or fewer substantive obligations; and (3) states or regional economic unions, such as the EU, calling for a shift from ad hoc tribunals in favour of the creation of a permanent investment law court. ${ }^{32}$

There are at least two discernible impacts—-both of which fall under the second category of backlash identified above, i.e. changes to the content of IIA terms - that the NAFTA experience arguably has had on investment treaty making and policy, both at the NAFTA level and more broadly: ${ }^{33}$ (1) the increased inclusion of NDTP provisions in treaties, often now as a matter of right, and (2) the specification in provisions on governing law that not only are the treaty interpretations offered by the

\footnotetext{
${ }^{30}$ Specifically, that the FET provision in the BIT in question (the Argentina-France BIT) should not be read to encompass legitimate expectations. See Suez, Sociedad General de Aguas de Barcelona SA and Vivendi Universal SA v. Argentina, ICSID Case No. ARB/03/19, Decision on Liability Separate Opinion of Pedro Nikken, 30 July 2010, para. 6.

${ }^{31}$ See Suez, Sociedad General de Aguas de Barcelona SA and Vivendi Universal SA v. Argentina, ICSID Case No. ARB/03/19, Decision on Liability - Separate Opinion of Pedro Nikken, 30 July 2010, para. 6 .

${ }^{32}$ See UNCTAD 2019 WIR, pp. 104 et seq. (describing various types of IIA reform) https://unctad. org/en/PublicationsLibrary/wir2019_en.pdf.

${ }^{33}$ The author does not discount that NAFTA might be one of several factors that has shaped the IIA policy making of countries in recent years.
} 
treaty parties binding on tribunals, but that decisions that the tribunals take must be consistent with such interpretations. ${ }^{34}$

In the NAFTA context, such backlash is visibly reflected in the text of the renegotiated NAFTA (renamed the United States-Mexico-Canada Agreement (USMCA)). ${ }^{35}$ The USMCA has vastly reduced ISDS provisions, only granting access to ISDS for investors in certain circumstances. ${ }^{36}$ However, despite this greatly reduced access to ISDS, and with respect to the first impact identified above, it is noteworthy that the NAFTA/USMCA parties not only preserved, but strengthened, NDTP participation provisions (USMCA adopts the nomenclature "Non-Disputing Annex Parties"), by granting the parties, e.g., the ability to attend hearings and make oral and written submissions on a matter of interpretation, indicating the value that the parties assign to the possibility of making such submissions. $^{37}$

With respect to the second impact, and almost certainly as a response to the FTC Notes/Pope \& Talbot situation, the USMCA provides in Article 14.D.9(2) that "a decision of the Commission on the interpretation of a provision on this Agreement under Article 30.2 (Functions of the Commission) shall be binding on a tribunal, and any decision or award issued by a tribunal must be consistent with that decision." 38 In contrast, NAFTA provided that "[a]n interpretation by the Commission of a provision of this Agreement shall be binding on a Tribunal established under this Section."39

Canada, one of the NAFTA/USMCA parties, has gone even further in its 2016 treaty with the EU, the Canada-EU Comprehensive Economic and Trade Agreement (CETA). CETA contains new-generation NDTP provisions permitting, amongst other forms of NDTP participation, a provision allowing NDTPs to file submissions on interpretation and to attend hearings. ${ }^{40}$ In addition, the CETA goes a step further, providing that on appeal, the appellate tribunal may modify or reverse a tribunal's award based on "errors in the application or interpretation of applicable law," which includes interpretations made by the treaty parties. ${ }^{42}$

\footnotetext{
${ }^{34}$ This category — and the trends analysed herein — relate solely to provisions generally stating that parties' agreed interpretations are binding on the tribunals. It does not examine separate but similar provisions that provide for such in special circumstances, such as when there are implications for financial services or taxation. See e.g. Article XI(1) of the Canada-Croatia BIT (1997).

${ }^{35}$ For example, ISDS is eliminated entirely between Canada and Mexico in the USMCA.

${ }^{36} \mathrm{~N}$ Bernasconi-Osterwalder, USMCA curbs how much investors can sue countries—sort of, IISD, www.iisd.org/library/usmca-investors.

${ }^{37}$ Article 14.D.7 of the USMCA.

${ }^{38}$ The same provision has been present in the US Model BIT since 2004. Article 30(3) of the 2004 US BIT and Article 30(3) 2012 US Model BIT.

${ }^{39}$ Article 1131 of NAFTA.

${ }^{40}$ Article 8.38 of CETA.

${ }^{41}$ Article 3.28(2) of CETA.

${ }^{42}$ Article 8.31 of CETA. However, the European Court of Justice, perhaps anticipating a Pope \& Talbot-esque scenario, has already stated that binding interpretations issued by the CETA Joint
} 
The other CETA party, the EU, is leading one of the most aggressive campaigns to change the status quo of ISDS, principally via its attempts to eliminate ad hoc ISDS tribunals in favour of variations of standing international investment courts with appellate mechanisms (one such example is contained in the CETA), as well as through its dogged efforts to attempt to eradicate intra-EU member state IIAs. The EU member states are party to hundreds of treaties, both between themselves and with other states, and some are among the most active in ISDS disputes both historically and recently. ${ }^{43}$ It is known that the EU has attempted to intervene in several ISDS cases $^{44}$ - and has been denied participation on several such occasions for various reasons, including its unwillingness to contribute to the arbitration $\operatorname{costs}^{45}$-and it is likely that it has attempted to intervene in many more disputes than can be identified publicly. ${ }^{46}$ To this end, the EU's recent treaty practice seems to prioritise ensuring that it may participate as an NDTP in future disputes; three of its IIAs contain provisions allowing for NDTP submissions (and the EU-Mexico agreement is reported to contemplate such), ${ }^{47}$ in addition to other provisions aimed at ensuring participation and safeguarding the treaty parties' ability to exert some form of interpretive regulation over arbitral tribunals.

It is notable that even while attempting to reform the IIA landscape amid the current backlash to ISDS, the EU in its treaties and the NAFTA parties in the USMCA retain NDTP provisions: in the latter case this is all the more striking given the limited scope of permissible ISDS disputes. This is reflective of a general trend that can be observed concerning the increasing inclusion of provisions ensuring and strengthening the participation of NDTPs in IIAs, which could be considered

Commission (i.e. the equivalent of the FTC) cannot have retroactive effect on pending or concluded ISDS proceedings. ECLI:EU:C:2019:341, Opinion 1:17 (Opinion Pursuant to Article 218 (11) TEFU), 30 April 2019, http://curia.europa.eu/juris/document/document.jsf?text=\& docid $=213502 \&$ pageInde $x=0 \&$ doclang $=$ EN \& mode $=1$ st $\&$ dir $=\& o c c=$ first $\&$ part $=1 \&$ $\mathrm{cid}=4976548$. For further discussion, see Titi (forthcoming).

${ }^{43}$ For example, the Netherlands (which is currently the second most frequent home state of investors in ISDS disputes) and Spain (which is currently the second most frequent respondent state). See Fact Sheet on Investor-State Dispute Settlement Cases in 2018, UNCTAD, IIA Issues Note, (May 2019), pp. 2-3, Figure 2 and 3, https://unctad.org/en/PublicationsLibrary/diaepcbinf2019d4_en. pdf.

${ }^{44}$ See e.g. Ioan Micula, Viorel Micula and others v. Romania, ICSID Case No. ARB/05/20, Decision on Annulment, 26 February 2016; Madsar Solar \& Wind Cooperatief UA v. Spain, ICSID Case No. ARB/14/1, Ruling on Application to Intervene as a Non-Disputing Party, 9 January 2015; United Utilities (Tallinn) B.V. and Aktsiaselts Tallinna Vesi v. Estonia, ICSID Case No. ARB/14/24, Decision on the Application for Leave to Intervene as a Non-Disputing Party, 2 October 2018.

${ }^{45}$ See Eiser Infrastructure Limited and Energía Solar Luxembourg Sàrl v. Spain, ICSID Case No. ARB/13/36, Procedural Order No. 7, 21 December 2015; UP and CD Holding Internationale v. Hungary, ICSID Case No. ARB/13/35, Decision on Application for Leave to Intervene as a Non-Disputing Party, 17 December 2014.

${ }^{46}$ See ICSID, Decisions on Non-Disputing Treaty Party Participation, https://icsid.worldbank.org/ en/Pages/Process/Decisions-on-Non-Disputing-Party-Participation.aspx.

${ }^{47}$ Article 3.51 of the EU-Vietnam IPA (2019), Article 3.17 of the EU-Singapore IPA (2018) and Article 8.38 of CETA. 
both part of the backlash and more generally part of IIA reform as countries update older-generation BITs that contained very few provisions to more comprehensive and detailed IIAs.

\section{NDTP Submission Trends in International Investment Law}

Turning back to NAFTA, the trends and backlash described above are reflected not only in the USMCA text, but also, to varying degrees, in the IIA practice of the individual NAFTA parties, which individually could be said to be on a sliding scale of conservative to progressive with respect to IIA liberalisation and innovation, with the United States falling on the conservative, protectionist end of the scale and Canada sitting on the other (although this has not always historically been the case). ${ }^{48}$

Starting at the conservative end of the spectrum, since 2008, the United States has stopped signing FTAs and BITs, and rather concludes Trade and Investment Framework Agreements (TIFAs), which establish basic institutional frameworks aimed at investment promotion and cooperation that contain no substantive obligations-it has concluded at least 13 such agreements since 2013. ${ }^{49}$ This notwithstanding, the 2012 US Model BIT contains provisions providing for NDTP participation and NDTP binding interpretations, ${ }^{50}$ and the United States had been involved in the negotiation of several so-called "mega-regional" agreements, such as the TransPacific Partnership (TPP), which likewise has a NDTP provision. ${ }^{51}$ (However, the United States withdrew from the TPP in 2017, causing the remaining Parties to enact the Comprehensive and Progressive Agreement for Trans-Pacific Partnership (CPTPP), which retains the NDTP submission provision. $)^{52}$ Of course, some of the FTAs to which the United States is party contain NDTP provisions, such as USMCA, showing the value that the US continues to place on the ability to make NDTP submissions.

In the middle of the spectrum of the NAFTA countries lies Mexico, which despite being a frequent ISDS respondent state, has concluded at least 22 BITs and 10 FTAs

\footnotetext{
${ }^{48}$ See Magraw (2019) (discussing the progression of the NAFTA parties' respective policies regarding international investment law in the twentieth and twenty-first centuries).

${ }^{49}$ The US signed its first TIFA in 1992 (with New Zealand) and concluded its most recent with Paraguay in 2016. UNCTAD, World Investment Report 2017, UN, p. 112, https://unctad.org/en/ PublicationsLibrary/wir2017_en.pdf. TIFAs typically contain less than 10 provisions, and their only firm commitment is the establishment of a joint council to monitor trade and FDI between the signatories.

${ }^{50}$ See Article 28(2) of the US 2012 Model BIT.

${ }^{51}$ Article 9.23 of the TPP.

${ }^{52}$ The CPTPP incorporates by reference much of the TPP, including the investment chapter, while suspending certain provisions that were included in the TPP at the behest of the US.
} 
since 2000, as well as drafted its 2008 Model Investment Promotion and Protection Agreement. ${ }^{53}$ Like Canada, it is a signatory to the CPTPP, which provides for NDTP participation. At least 10 of the IIAs to which Mexico is a party contain a provision allowing for NDTP submissions, and Mexico concluded the second known treaty providing for such. ${ }^{54}$ Furthermore, the EU and Mexican Investment Protection Agreement, the draft of which contains a provision on NDTP submissions, ${ }^{55}$ is reportedly even more progressive than the CETA. ${ }^{56}$

On the other side of the spectrum, all of Canada's recent treaties except for one have contained NDTP provisions, ${ }^{57}$ possibly based on its NAFTA Article 1128 experience. ${ }^{58}$ Canada did not sign any BITs between 1999 and 2005; in 2006, it began concluding them again — to date, at least 44 (approximately half of its 44 IIAs post-2006). Subsequent to NAFTA until 1999, it entered into several bilateral and regional "cooperation agreements" (which do not contain substantive obligations; rather they state the parties' intentions to cooperate to liberalise and promote FDI, and establish a joint committee). Starting in 2001, Canada concluded several bilateral and regional FTAs, including the CETA in 2016, which establishes a joint body with the power to issue binding interpretations and an NDTP provision.

Canada's approach could be considered reflective of a broader trend that can be generally discerned from the text of many recent IIAs, i.e. a growing number of treaties containing increasingly sophisticated NDTP provisions, which has been identified as one of the likely impacts of the NAFTA experience in the previous section (although arguably in conjunction with other factors as well). For instance, in addition to the increase of specific provisions addressing NDTPs as a separate category of submissions from amicus curiae and establishing joint bodies with mandates to issue binding interpretations of treaty provisions, ${ }^{59}$ a rising number of IIAs and related instruments provide for NDTP submissions by right (i.e., such submissions must be allowed by tribunals) on matters of treaty interpretation. Globally, there are at least 82 IIAs that contain explicit NDTP provisions, not to mention treaties that incorporate the 2014 Rules on Transparency in Treaty-based

\footnotetext{
${ }^{53}$ Mexico has recently joined the ICSID Convention. ICSID News Release (11 January 2018) https://icsid.worldbank.org/en/Pages/News.aspx?CID=267.

${ }^{54}$ See Annex 5 of the Mexico-Venezuela-Bolivia FTA (1994).

${ }^{55}$ Article 23(3) of the EU-Mexico Agreement (2018), Section [X]: Resolution of Investment Disputes, https://trade.ec.europa.eu/doclib/docs/2018/april/tradoc_156814.pdf.

${ }^{56}$ See Charlotin and Hepburn, Analysis: EU-Mexico investment text released, allowing for comparison with other agreements; permanent two-tier system of adjudication is envisioned, Investment Arbitration Reporter (2 May 2018) https://www.iareporter.com/articles/analysis-eu-mexicoinvestment-text-is-released-allowing-for-comparison-with-other-agreements-permanent-two-tiersystem-of-adjudication-is-envisioned/.

${ }^{57}$ See UNCTAD Investment Policy Hub, IIA Navigator, https://investmentpolicy.unctad.org/ international-investment-agreements.

${ }^{58}$ Newcombe (2005), p. 1.

${ }^{59}$ See Australia-Peru FTA (2018); Belarus-India BIT (2018); Central America-Republic of Korea FTA (2018); CPTPP (2018); EU-Singapore IPA (2018); EU-Vietnam IPA (2019); USMCA (2018); and the Netherlands Model BIT (2018).
} 


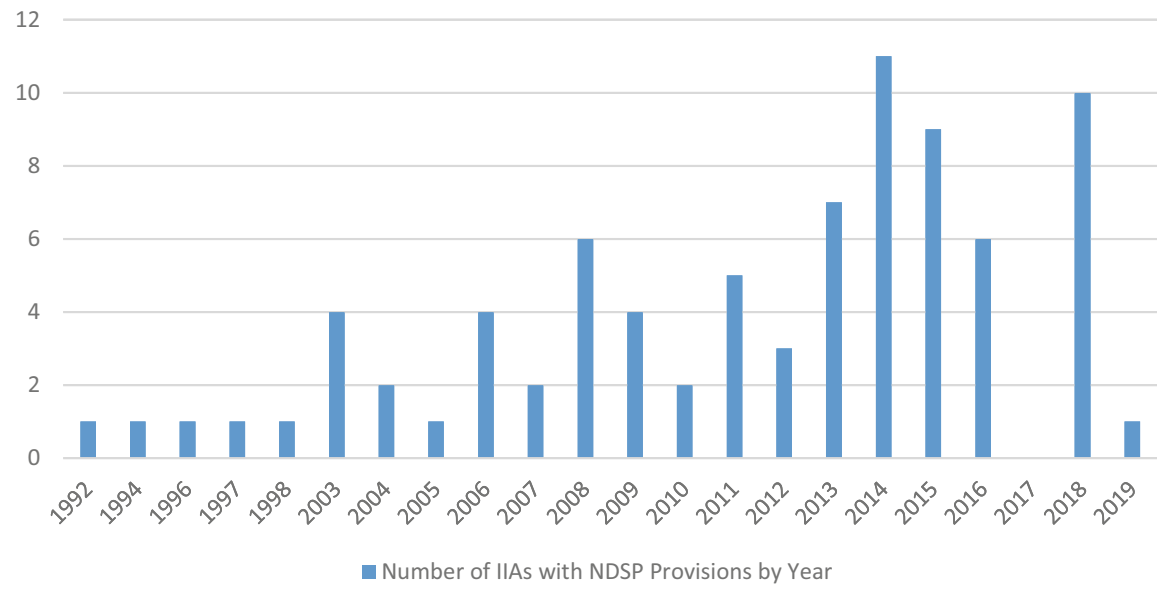

Fig. 1 Number of IIAs with NDSP provisions by year (Source: UNCTAD IIA Navigator)

Investor-State Dispute Settlement of the United Nations Commission on International Trade Law (UNCITRAL) (which provides for NDTP submissions): ${ }^{60}$ notably, only five of the 82 known IIAs containing NDTP provisions-including NAFTAwere concluded prior to 2003, and all of those five were concluded by at least one NAFTA party; 2003 also appears to be the first year that non-NAFTA parties concluded a treaty with a NDTP provision. ${ }^{61}$ Since then it has been off to the races, as is evident from Fig. 1: 55 of the 82 known treaties identified in the data analysis for this chapter that permit NDTP submission provisions were concluded since 2010, demonstrating the massive uptick in the conclusion of such treaties in recent years. $^{62}$

This trend shows no sign of slowing down: approximately one-third of the treaties concluded in 2018 contained an NDTP submission provision. ${ }^{63}$ As evident from Fig. 2, nearly $60 \%$ of the sample IIAs containing NDTP provisions have been concluded post-2010.

This is all the more noteworthy considering that the conclusion of IIAs has declined since 2010, as visible in Fig. 3, making the high occurrence of NDTP provisions in the 2018 treaties all the more significant.

The above trend could potentially be traced to the timeline of the very high-profile disputes surrounding the NDTP submission and FTC Notes controversy described above: the issue of the status of the states' SPPs was discussed in several cases

\footnotetext{
${ }^{60}$ See UNCTAD Investment Policy Hub, IIA Navigator, https://investmentpolicy.unctad.org/ international-investment-agreements. IIAs incorporating the 2014 UNCITRAL Transparency Rules were not analysed for purposes of this chapter.

${ }^{61}$ Article 10.32 of the Chile-Republic of Korea FTA (2003).

${ }^{62}$ See UNCTAD Investment Policy Hub, IIA Navigator, https://investmentpolicy.unctad.org/ international-investment-agreements.

${ }^{63}$ See UNCTAD Investment Policy Hub, IIA Navigator, https://investmentpolicy.unctad.org/ international-investment-agreements.
} 


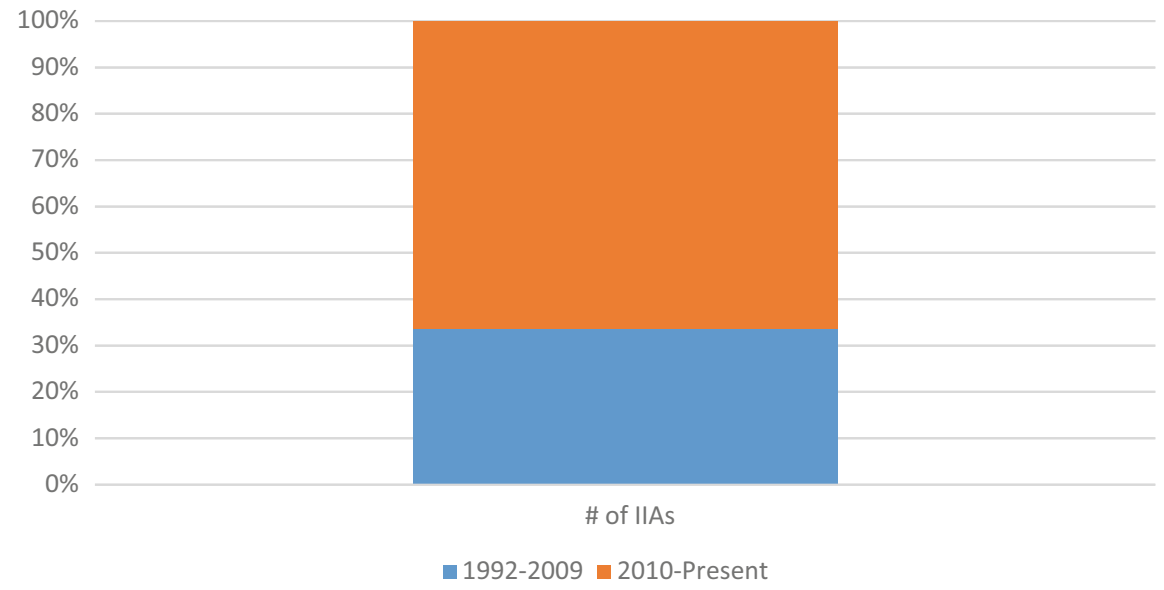

Fig. 2 IIAs with NDSP pre- and post-2010 (Source: UNCTAD IIA Navigator)

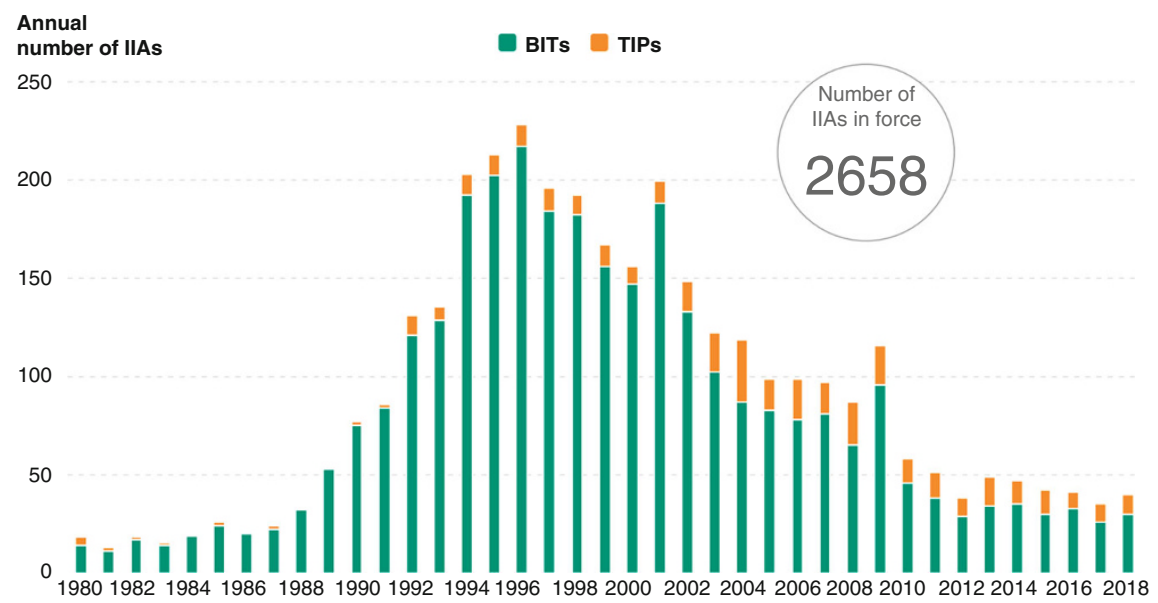

Fig. 3 Number of IIAs signed, 1980-2018 (Source: UNCTAD 2019 WIR Figure 111.7, p. 99; UNCTAD, IIA Navigator)

leading up to the 2001 issuance of the FTC Notes, and the binding nature of the FTC Notes continued to be debated by tribunals in decisions issued from between 2001 and $2010 .{ }^{64}$ The subsequent reaction vis-à-vis increased inclusion of NDTP submissions in IIAs by not only the NAFTA parties but also other states was probably

${ }^{64}$ See Sect. 2 above. 
affected by this ongoing debate. The above trends are also being seen at the institutional and multilateral level: for example, the 2018 proposed ICSID arbitration rule revisions contain such a provision for the first time ${ }^{65}$ and the 2014 United Nations Convention on Transparency in Treaty-based Investor-State Arbitration contains a provision on NDTPs. ${ }^{66}$ States have very important and often primary roles in shaping the direction of such rules and conventions. ${ }^{67}$

Turning to the second trend that is arguably also linked to the NAFTA experience, i.e. the coupling of provisions providing for binding interpretations and consistent decisions, similar trends to the NDTP provisions can be identified from the available data. NAFTA was the first known-IIA to contain a provision that the parties' interpretations are binding on a tribunal. Subsequent to NAFTA, approximately 14 IIAs that were concluded between 1994 and 2002 contained such provisions, all of which were BITs concluded by a NAFTA party (predominantly Mexico) and a third party. In 2002, the Pope \& Talbot final Award was rendered. In 2003, for the first time, two US IIAs contained the requirement that tribunals' decisions must be consistent with the treaty parties' binding interpretations. ${ }^{68}$ In the sample of IIAs containing NDTP provisions concluded between 2003 and 2009, approximately 27 provided either for binding interpretations alone (16) or binding interpretations coupled with consistent decisions (11). Of these 11 providing also for consistent decisions, over half were concluded by a NAFTA party (namely Canada or the US). However, a handful of South American countries ${ }^{69}$ started including them in their treaties during this period, and both were also provided for in the 2009 Comprehensive Investment Agreement of the Association of Southeast Asian Nations (ASEAN), demonstrating that non-NAFTA parties were beginning to pick

\footnotetext{
${ }^{65}$ See proposed Article 49 of the Rule Revisions (or Article 58 of the Additional Facility Rules). Proposals for Amendment of the ICSID Rules, ICSID, Working Paper Vol 3, August 2019, https:// icsid.worldbank.org/en/Documents/WP_3_VOLUME_1_ENGLISH.pdf.

${ }^{66}$ Furthermore, at least two treaties (both of which were concluded by Canada) specifically provide that the Rules on Transparency apply (Article 8.36 of CETA and Article 29 of the Canada-Hong Kong BIT (2016)); however, as the 2013 UNCITRAL Rules incorporate the Mauritius Convention, the number of arbitral proceedings that may have to be conducted in accordance with the Mauritius Convention (which entered into force in 2017), including the opportunity for NDTP to make submissions, is much higher.

${ }^{67}$ For example, states are invited to submit comments on the ICSID Rule revisions. Mexico, for example, has commented on the content of the proposed NDTP provision in the new ICSID rules. 'Comentarios de México al Proyecto de enmiendas a las reglas del CIADI', June 2019, https://icsid. worldbank.org/en/amendments/Documents/Mexico_CommentsWP2_06.24.2019.pdf. See generally https://icsid.worldbank.org/en/amendments.

${ }^{68}$ Article 15.21(2) of the Singapore-United States FTA (2003) and Article 10.21of the Chile-United States FTA (2003).

${ }^{69}$ Namely, Chile, Colombia and Peru: Peru concluded a BIT with Canada in 2006 providing for both binding interpretations and consistent decisions, and Chile did the same in the 2003 FTA with the United States. The Chile-Peru FTA (2006), Chile-Colombia FTA (2006) and the Colombia-Peru BIT (2007) then became the first three (known) non-NAFTA party IIAs to provide for both binding interpretations and consistent decisions.
} 


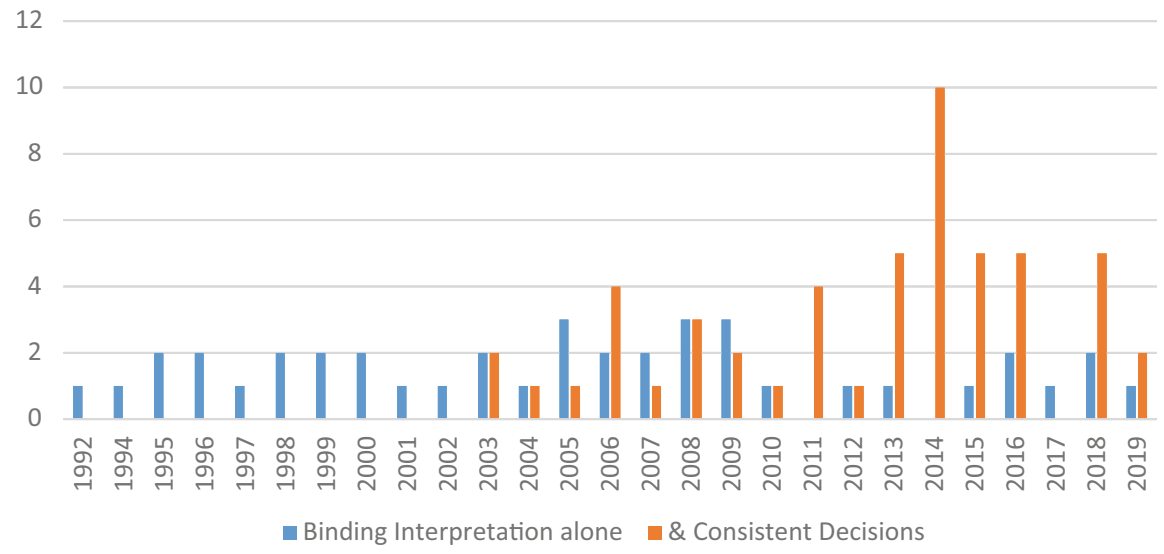

Fig. 4 IIAs with provisions on binding interpretations and consistent decisions (Source: UNCTAD IIA Navigator)

up this IIA practice. In 2010 the Merrill \& Ring decision was handed down; from 2010 onward, the inclusion of such provisions in IIAs took off.

All in all, and as can be seen in Fig. 4, since the "binding interpretation" provision was first expanded upon to specify that tribunals' decisions needed to be consistent therewith in 2003, at least 38 treaties have been concluded that provide for both, and although the NAFTA parties—especially Canada—have continued to include them in their recent treaties, many of the most recent IIAs have been concluded by non-NAFTA parties, including the EU. ${ }^{70}$

The trends observable in recent IIAs indicate that states wish to strengthen their ability to participate in disputes, especially on matters of treaty interpretation, and to further ensure that tribunals take due account of such interpretations, as reflected in the numerous treaties concluded subsequent to this period that contain NDTP submissions and/or provisions providing for binding interpretations/consistent decisions.

\section{Conclusions}

The above tends to demonstrate that the lack of deference afforded by tribunals to the interpretations of states given during disputes - or even to the treaty parties' binding interpretations, such as the FTC Notes-may be contributing to the current backlash against the ISDS system, which has taken many forms. It is also evident that IIA reform is occurring within the context of this backlash, possibly as a reaction to the

\footnotetext{
${ }^{70}$ See UNCTAD Investment Policy Hub, IIA Navigator, https://investmentpolicy.unctad.org/ international-investment-agreements.
} 
prior stances taken by some tribunals concerning NDTP submissions, often with the states' intent being to enhance their ability to participate as NDTPs in disputes concerning treaties to which they are parties and to ensure that the decisions taken by tribunals are consistent with the treaty interpretations that states provide. Thus, even as some countries "disengage" from ISDS or modify their IIA and investment policy practice, states (and regional economic unions) appear to highly value the ability to submit NDTP submissions in on-going disputes, as is evident from recent IIAs and similar trends in the international investment regime (such as the proposed amendments to the ICSID Arbitration Rules), which shows no sign of slowing down anytime soon.

\section{References}

Alvarez GA, Park WW (2006) The new face of investment arbitration: NAFTA chapter 11. Yale J Int Law 28:347

Brower C II (2001) Investor-state disputes under NAFTA: the empire strikes back. Columbia J Transnatl Law 40

Brower C II (2006) Why the FTC notes of interpretation constitute a partial amendment of NAFTA article 1105. Va J Int Law 46

Gordon K, Pohl J (2015) Investment treaties over time - treaty practice and interpretation in a changing world, OECD Working Papers on International Investment (2015/2). OECD, Paris

Magraw K (2015) Investor-state disputes and the rise of recourse to state party pleadings as subsequent agreements or subsequent practice under the Vienna Convention on the Law of Treaties. ICSID Rev - Foreign Invest Law J 30:142

Magraw K (2019) North America. In: Krajweski M, Hoffmann R (eds) Research handbook on foreign direct investment. Edgar Elgar

Matiation S (2014) Arbitration with two twists: Loewen v United States and free trade commission intervention in NAFTA chapter 11 disputes. Univ Pa J Int Law 24(2):451

Newcombe A (2005) Canada's new model foreign investment protection agreement, TDM 120051

Palchetti P (2002) Opening the International Court of Justice to third states: intervention and beyond. Max Planck UNYB 138:6

Polanco R (2019) Return of the home state in investor-state disputes: bringing back diplomatic protection? Cambridge University Press, Cambridge

Titi C (forthcoming) Opinion 1/17 and the future of investment dispute settlement: implications for the design of a multilateral investment court. In: Sachs L, Johnson L (eds) Yearbook on International Investment Law \& Policy 2019. Oxford University Press. A working version of this paper is available at https://papers.ssrn.com/sol3/papers.cfm?abstract_id=3530875

Weiler T (2002) NAFTA investment law in 2001: as the legal order starts to settle, the bureaucrats strike back. Int Law 36 
Kendra Magraw specialises in international arbitration, particularly international investment and sports arbitration. Amongst others, she has worked in private practice, as well as at UNCTAD's International Investment Agreements Section and on one of the case management teams at ICSID. She is a PhD candidate in international law at the Graduate Institute in Geneva.

Open Access This chapter is licensed under the terms of the Creative Commons Attribution 4.0 International License (http://creativecommons.org/licenses/by/4.0/), which permits use, sharing, adaptation, distribution and reproduction in any medium or format, as long as you give appropriate credit to the original author(s) and the source, provide a link to the Creative Commons license and indicate if changes were made.

The images or other third party material in this chapter are included in the chapter's Creative Commons license, unless indicated otherwise in a credit line to the material. If material is not included in the chapter's Creative Commons license and your intended use is not permitted by statutory regulation or exceeds the permitted use, you will need to obtain permission directly from the copyright holder.

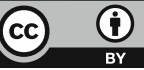

